\title{
STUDIES ON CALCIUM CONTENT IN SEA WATER. II. DISTRIBUTION OF CALCIUM IN THE ATLANTIC WATER OFF SOUTH BRAZIL
}

(Received for publication in 1959)

\author{
Kenji Kato * \\ Faculty of Fisheries, Hokkaido University - Japan \\ Oceanographic Institute, University of São Paulo - Brazil
}

\begin{abstract}
SYNOPSIS
In the present paper, the regional distribution of calcium in the Atlantic water off South Brazil was examined oceanochemically by analyses of calcium contents in 78 water samples which had been collected off the coast of the São Paulo State. The chelatometric titration with EDTA reagent was employed in these analyses of calcium with good results.

Calcium content of the water in the present area bears an almost direct relation to the chlorinity. The estimate of $\mathrm{Ca} / \mathrm{Cl}$ is $21.56 \times 10^{-3}$. Allowance has been made for the strontium included in the estimate for calcium. The estimate of $\mathrm{Ca} / \mathrm{Cl}$ as mentioned above is much the same as that made by other researchers, and the $\mathrm{Ca} / \mathrm{Cl}$ factor of the Atlantic water appears to be lower than that of the Pacific water.

It is of great interest that the distribution of calcium in the water shows close correlation to the oceanographic condition in the present area of the South Atlantic Ocean. Namely, the surface water of the Brazil Current gave a relatively low estimate of $\mathrm{Ca} / \mathrm{Cl}$ as $21.4 \times 10^{-3}$ compared with that of the subsurface water, where it is $22.0 \times 10^{-3}$ or more. Such a close relation between them certainly suggests that the $\mathrm{Ca} / \mathrm{Cl}$ factor is an appreciable clue for distinguishing different water masses in a definite area.

A characteristically minimum zone of calcium content was observed in the subsurface layer at the approximate depth of $50 \mathrm{~m}$ in the off-shore station (St. 69). This minimum zone can be attributed to the increased development of zooplankton populations, whose active respiration causes a high consumption of dissolved oxygen in a degree of saturation of $70 \%$ in the water of this zone. This distribution aspect of the calcium is noteworthy as it shows a close relation between calcium-utilizing organisms and their biochemical and ecological conditions.
\end{abstract}

\section{INTRODUCTION}

In oceanic water away from terrigenous influences, the quantity of calcium, as pointed out by many researchers (Lyman \& Fleming 1940; ThompSON \& Wright 1930; KIRK \& Moberg 1933), is definitely correlated to the corresponding chlorinity. However, in the upper euphotic zone, a slight divergence from the constancy in the ratio of calcium to chlorinity is sometimes observed on account of active development of plankton populations. In deep water over the oceanic bottom floor, the tremendous hydrostatic-pressure of the water causes a dissolution

- At present in the Faculty of Fisheries, Prefectural University of Mie, Tsu, Japan. of the calcium from the bottom (WATtenberG, 1933).

The distribution of calcium in sea water in the littoral region is remarkably affected by the predominant supplies of terrigenous waters. GRIPENBERG (1937) distinguished several different masses of water in the Baltic Sea, where low salinity water of about $6 \%$ is generally found in the deeper layer, diluted by the tremendous amount of land water which runs into the area, by means of the deviation of the ratio $\mathrm{Ca} / \mathrm{Cl}$.

Although a fairly large number of publications have hitherto been presented by many researchers in relation to calcium in the sea water, very few re- 
ferences were available dealing with the regional distribution of calcium content as based on the practical determination of calcium in the water. Even in such synthetic observations of oceanography as the 'Meteor' Expedition (Wattenberg, 1933) or the Swedish Deep-Sea Expedition (Bruneau et al., 1953), there are no actual determinations of calcium in sea water itself, but measurements of alkalinity, $\mathrm{pH}$ and chlorinity of the water samples were made so as to estimate the calcium content.

Till now few works are available related to the distribution of calcium in the Southern Atlantic, especially off South Brazil. As mentioned above, WATTENBERG (1933) investigated a probable feature of the distribution of calcium carbonate in the Atlantic water studying data on the alkalinity of the water. In his investigation, the observed area was principally located in the equatorial region of the Southern Atlantic. Thus, only a few stations where he actually observed the alkalinity of sampled waters were situated in the Southern Atlantic off the South of Brazil.

The calcium contents of 78 samples from the South Atlantic water were determined by the author for the purpose of examining actual distribution of calcium in this area from oceanographic and ecological points of view. In determining calcium from these water samples, the author's own method (KATo, 1966a) was employed with satisfactory results.

\section{EXPERIMENTAL}

The water samples were collected during the period from the $31^{\text {st }}$ of October to the $5^{\text {th }}$ November 1956, during the third cruise of the corvette 'Solimões' from the Brazilian Navy (Emilsson, 1956). They were stored in the Section of Physical Oceano= graphy, Oceanographic Institute, University of São Paulo.

The chelatometric titration, as described in the previous paper, was applied to determine the calcium content of these samples. The standard error of a single determination was $\pm 0.4 \%$. All analyses were made at least in duplicate, several samples being analysed three or four times. Table I gives the means of all the analyses.

The calcium content was determined in $\mathrm{mg} / \mathrm{l}$ and reduced by calculation to $\mathrm{mg} / \mathrm{kg}$. The corresponding oceanographic data referred were taken from the report published by the Section of Physical Oceanography (EmiLsson, 1956).

When the investigation was undertaken, the samples had been stored for a year and half, but the fact that the chlorinity in most cases agreed with those determined in 1956 in samples from the same localities and depths showed that no appreciable evaporation had taken place. The localities from which the water samples were collected are illustrated in Figure 1, and the results are summarized in Table I.

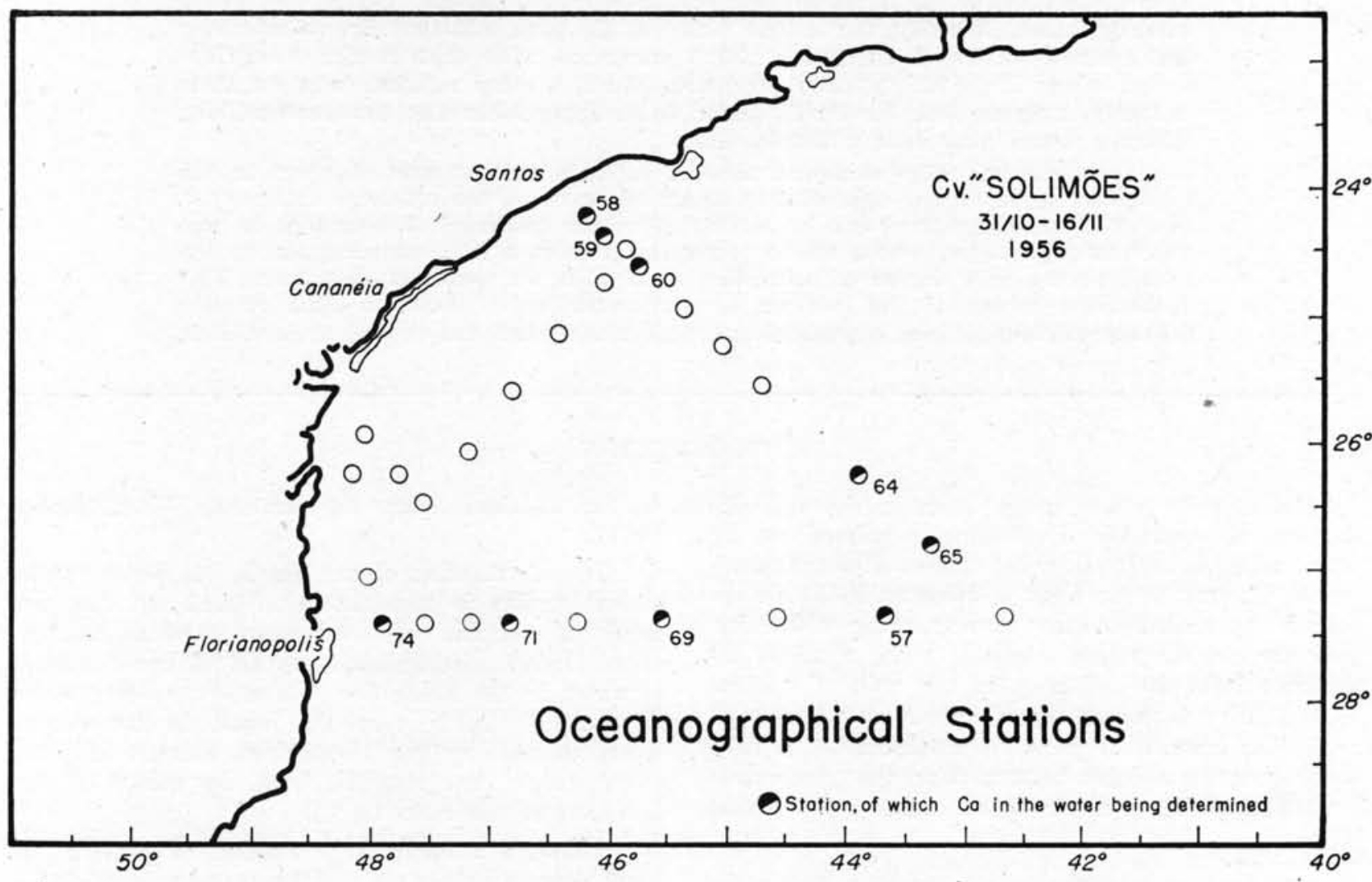

Fig. 1 - Location of observed stations. 
TABLE I - Calcium content of the Atlantic water off South Brazil

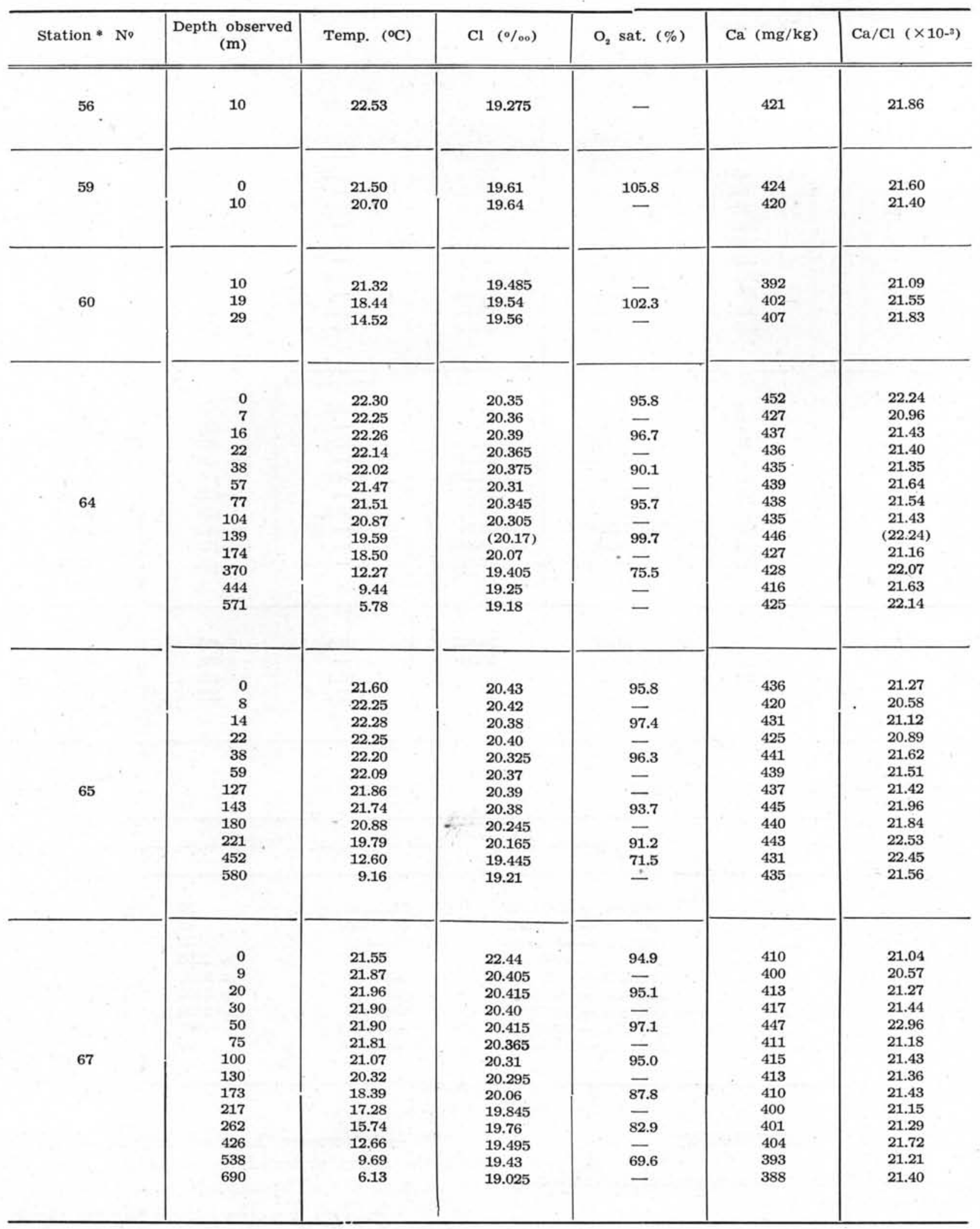

(Continued) 
TABLE I (Continuation)

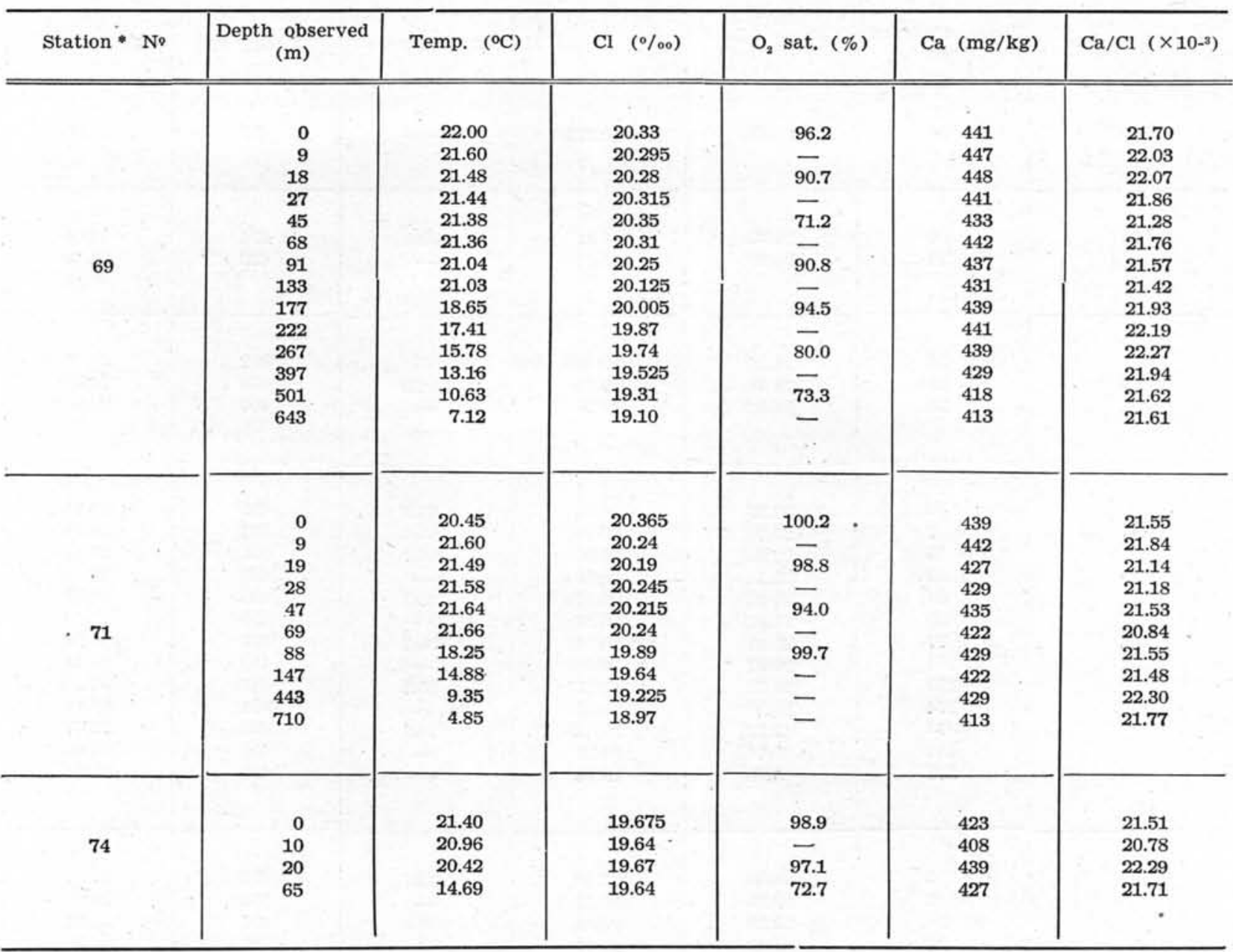

* Note - Additional data to Table I.

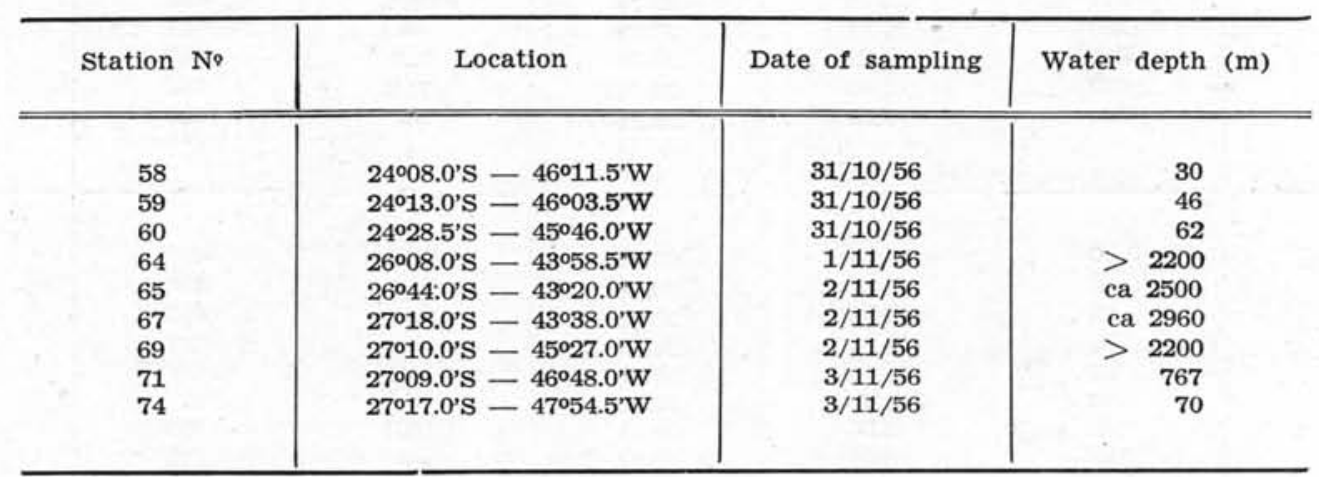

\section{DISCUSSION}

\section{Relation between calcium content and chlorinity} in sea water

A definite relation will be found, as shown in Table I, between the calcium content and the chlorinity of the water sample, whereby the ratio of $\mathrm{Ca}$ to $\mathrm{Cl}$ averages up to $21.56 \times 10^{-3}$ in the present study.
So as to compare the above estimate of $\mathrm{Ca} / \mathrm{Cl}$ with the others presented up to date, a series of the estimates of $\mathrm{Ca} / \mathrm{Cl}$ presented by many researchers are listed in Table II. The present estimate agrees pronouncedly with the others. In the Table allowance was made for the strontium included in the estimation of calcium. In the chelatometric determination, strontium is included in the titre and causes a drawn out end-point (SchWARZENBACH, 1957). 
TABLE II - The ratio of calcium content to chlorinity in sea water

\begin{tabular}{|c|c|c|}
\hline Author & Location & $\begin{array}{c}\mathrm{Ca} / \mathrm{Cl} \\
\left(\times 10^{-3}\right)\end{array}$ \\
\hline $\begin{array}{l}\text { Dittmar (1884) (recal- } \\
\text { culated by Lyman \& } \\
\text { Fleming, 1940) }\end{array}$ & (oceans) & 20.95 \\
\hline $\begin{array}{l}\text { Thompson \& Wright } \\
\text { (1930) }\end{array}$ & North Pacific Ocean & 20.90 \\
\hline Kirk \& Moberg (1933) & $\begin{array}{l}\text { North Pacific Ocean } \\
\text { (coast of Southern } \\
\text { California) }\end{array}$ & 21.54 \\
\hline Gripenberg (1937) & North Atlantic Ocean & 21.56 \\
\hline $\begin{array}{l}\text { Kato (in the present } \\
\text { paper) }\end{array}$ & $\begin{array}{l}\text { South Atlantic Ocean } \\
\text { (off South Brazil) }\end{array}$ & 21.56 \\
\hline Sverdrup et all. (1942) & (oceans) & $\begin{array}{c}21.76 \\
\text { (Sr: } 0.70)\end{array}$ \\
\hline $\begin{array}{l}\text { Chow \& Thompson } \\
\text { (1955) }\end{array}$ & $\begin{array}{l}\text { North Pacific _Ocean } \\
\text { (Gulf of Alaska) }\end{array}$ & $\begin{array}{c}22.42 \\
(\mathrm{Sr}: 0.48)\end{array}$ \\
\hline Sugawara (1955) & $\begin{array}{l}\text { Northwestern Pacific } \\
\text { Ocean (off Japan) }\end{array}$ & $\begin{array}{c}23.21 \\
(\mathrm{Sr}: 0.47)\end{array}$ \\
\hline
\end{tabular}

In general, the strontium content in the sea water amounts to about $3.2 \%$ of the calcium content; $\mathrm{Sr} / \mathrm{Cl}$ is approximately $0.70 \times 10^{-3}$ (SverdRup et al., 1942). Mryake (1939) estimated the ratio of $\mathrm{Sr} / \mathrm{Cl}$ to 0.75 dealing with the Kuroshio Water of the Northwestern Pacific, while Chow \& Thompson (1955) calculated a ratio of $\mathrm{Sr} / \mathrm{Cl}$ of $0.42 \times 10^{-3}$ for the Atlantic Water.
Bruneau et al. (1953), in the Swedish DeepSea Expedition, estimated the $\mathrm{Ca} / \mathrm{Cl}$ factor, after his determinations of alkalinity and $\mathrm{pH}$ of the water samples, pointing out that the $\mathrm{Ca} / \mathrm{Cl}$ factor has a larger value in the Pacific water than in the Atlantic water. A similar feature of the local deviation of the $\mathrm{Ca} / \mathrm{Cl}$ in sea water is demonstrated in Table II.

As it is difficult to find publications on the actual distribution of calcium in the South Atlantic Ocean, the author calculated the probable quantities of calcium in the Atlantic off Brazil using the data on alkalinity of the water published by WATTENBERG (1933) with the following formula:

$$
\begin{array}{r}
\mathrm{Ca}(\mathrm{mg} \text {-atoms } / \mathrm{l})=\frac{\text { alkalinity }}{2}+0.465 \times \text { chlorinity } \\
(\text { SVERDRUP } \text { et al., 1942) }
\end{array}
$$

The estimates 20.4-20.6 $\times 10^{-3}$, shown in Table III, may not always be trustworthy enough for demonstrating the actual feature of calcium distribution in the present area, because of the small number of available data. The author's estimate $21.56 \times 10^{-3}$, seems comparatively larger than the above estimates from WatTEnBERG's data, but it should be noted that the present estimate, $21.56 \times 10^{-3}$, of $\mathrm{Ca} / \mathrm{Cl}$ involves that of $\mathrm{Sr} / \mathrm{Cl}$, approximately $0.70 \times 10^{-3}$. Consequently, the correct value of $\mathrm{Ca} / \mathrm{Cl}$, excepting the value of $\mathrm{Sr} / \mathrm{Cl}$, in the present investigation is estimated to approximately $20.86 \times 10^{-3}$, agreeing fairly well with the values calculated from the WATTENBERG's data.

TABLE III - Distribution of calcium in the South Atlantic water, off Brazil, as estimated from the

\begin{tabular}{|c|c|c|c|c|c|c|}
\hline Station No & Location & $\begin{array}{l}\text { Depth observed } \\
(\mathrm{m})\end{array}$ & Alkalinity & $\mathrm{Cl}(\%)$ & $\begin{array}{l}\mathrm{Ca}(\mathrm{mg} / \mathrm{kg}) \\
\text { calc. }\end{array}$ & $\begin{array}{l}\mathrm{Ca} / \mathrm{Cl}\left(\times 10^{-3}\right) \\
\text { calc. }\end{array}$ \\
\hline 156. & $\begin{array}{l}15^{\circ} 17.6^{\prime} \mathrm{S} \\
25^{\circ} 56.0^{\prime} \mathrm{W}\end{array}$ & 200 & 2.301 & 19.69 & 402 & 20.42 \\
\hline 161 & $\begin{array}{l}17^{\circ} 42.3^{\prime} \mathrm{S} \\
37^{\circ} 53.0^{\prime} \mathrm{W}\end{array}$ & 60 & 2.346 & 20.47 & 418 & 20.43 \\
\hline 162 & $\begin{array}{l}17^{\circ} 55.1^{\prime} \mathrm{S} \\
37^{\circ} 09.8^{\prime} \mathrm{W}\end{array}$ & 627 & 2.237 & 19.08 & 390 & 20.42 \\
\hline 200 & 8059.6's & 0 & 2.423 & 20.01 & 412 & 20.57 \\
\hline & $25^{\circ} 59.7 \mathrm{~W}$ & 200 & 2.364 & 19.56 & 401 & 20.49 \\
\hline 203 & $\begin{array}{l}11^{\circ} 50.0^{\prime} \mathrm{S} \\
35^{\circ} 12.0^{\prime} \mathrm{W}\end{array}$ & $\begin{array}{r}0 \\
50\end{array}$ & $\begin{array}{l}2.452 \\
2.457\end{array}$ & $\begin{array}{l}20.36 \\
20.46\end{array}$ & $\begin{array}{l}418 \\
413\end{array}$ & $\begin{array}{l}20.54 \\
20.19\end{array}$ \\
\hline
\end{tabular}
available data of WATTENBERG (1933)

3. Relation of calcium distribution to its oceanographic environment in the Atlantic water off South Brazil

Off South Brazil, the Atlantic Central Water spreads from the surface to a depth of approximately $.600-700 \mathrm{~m}$. This entire water mass forms a certain kind of 'Troposphere'. According to Defant's definition, by sinking within the Subtropical Convergenee between latitudes $30^{\circ}$ and $40^{\circ} \mathrm{S}$. Below the Central Water the Antarctic Intermediate Water, with low salinity near $34.6 \%$, is found over the deep and the bottom water. These waters are present below the Intermediate Water and are of greater thickness than the two other water masses together. In the Central Water the Brazil Current is the most outstanding current off Brazil, moving waters of high salinity and high temperature in the surface down to a depth of about $150 \mathrm{~m}$ to $200 \mathrm{~m}$ and proceeding to the south along the Brazilian coast.

To find out whether any correlation between the calcium distribution and its corresponding oceanographic condition exists in the present area off Brazil is of great interest. This correlation gives a certain clue to distinguish different water masses from each other both from the oceanographic and from the biological point of view. 


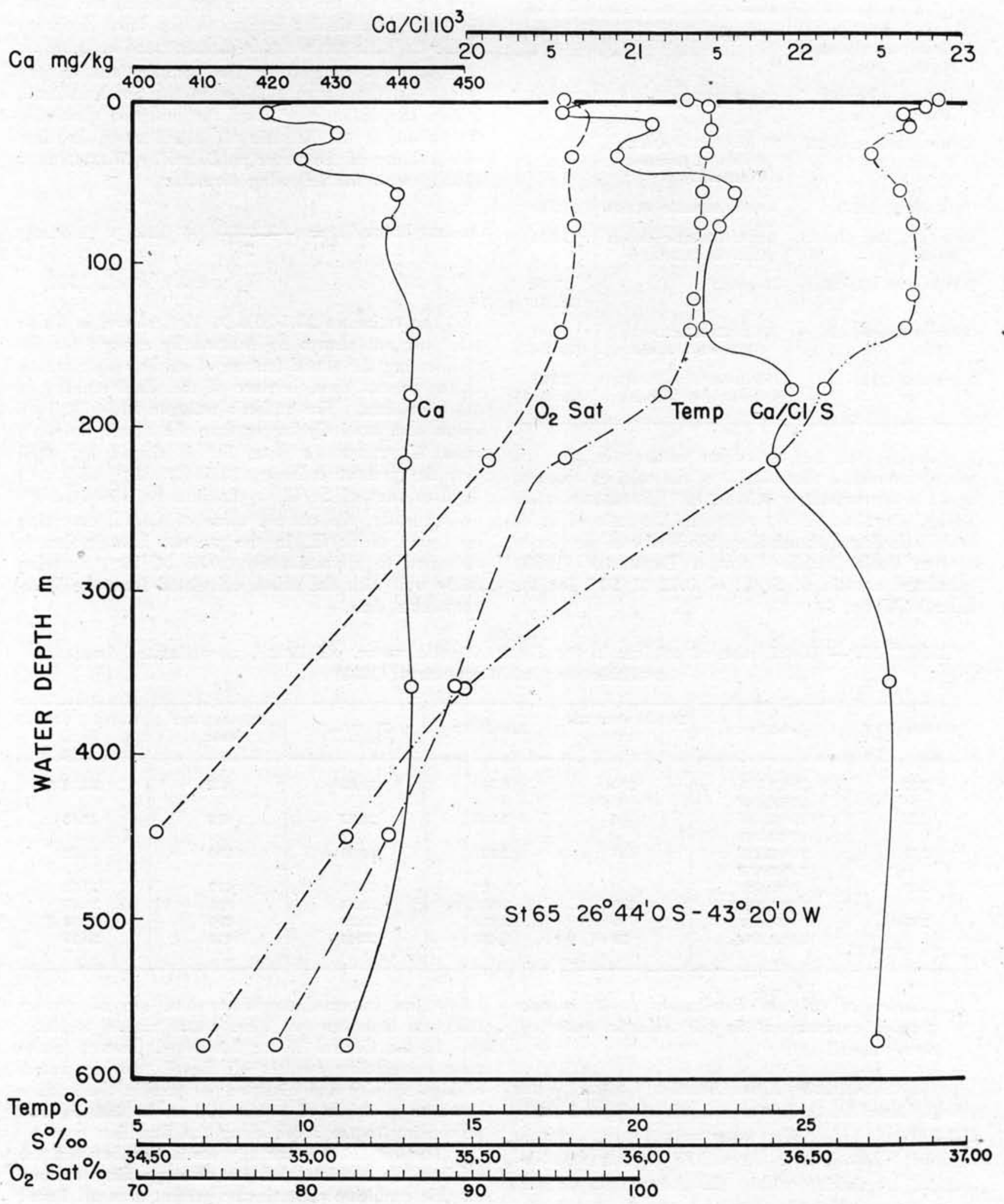

Fig. 2 - Relation of calcium distribution to its oceanographic environment in the Atlantic water off South Brazil No. 1. 

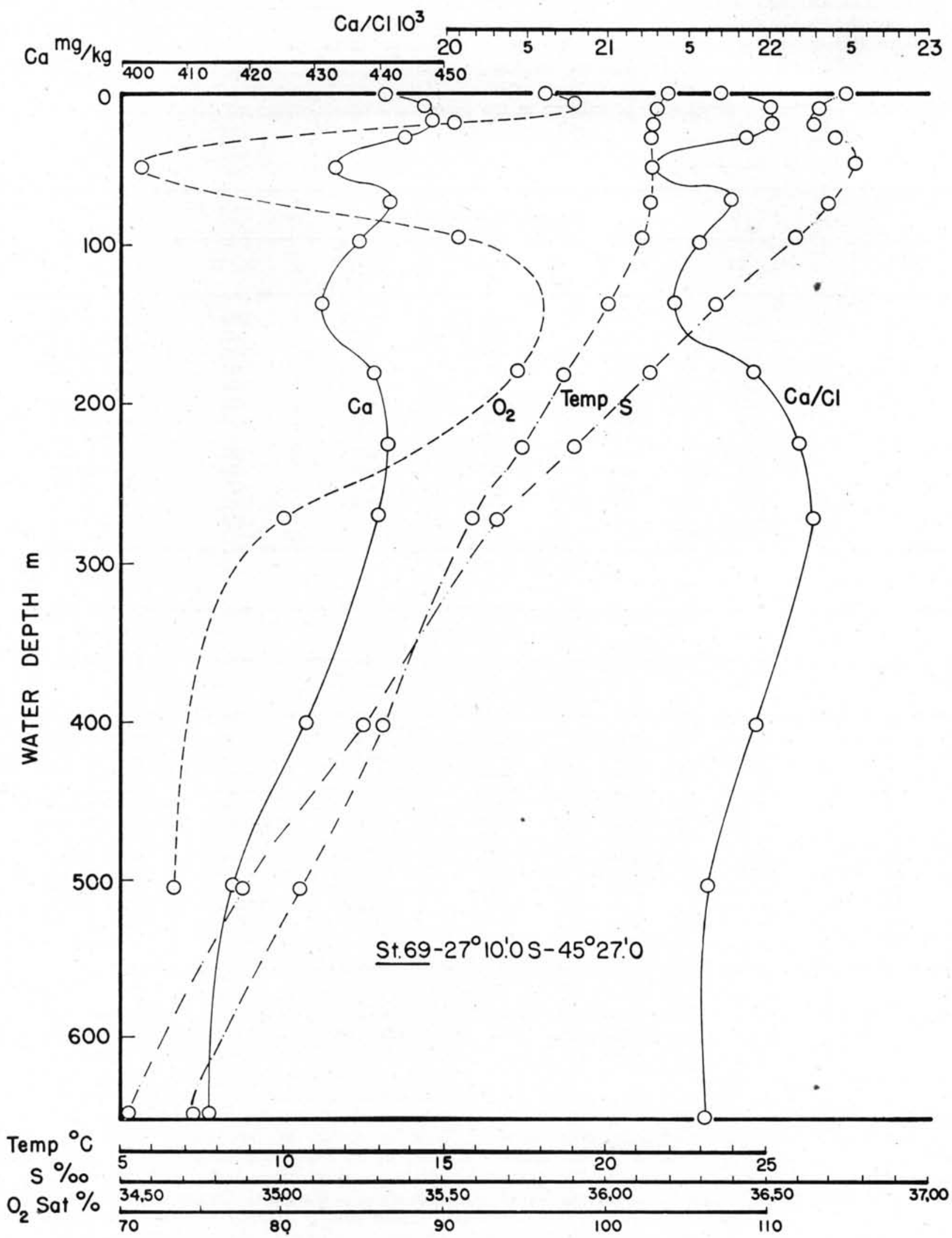

Fig. 3 - Relation of calcium distribution to its oceanographic environment in the Atlantic water off South Brazil No. 2. 
Figures 2 and 3 illustrate the typical features of the vertical distribution of calcium observed in the off-shore stations. Moreover, so as to obtain a probably definite characteristic of the calcium distribution throughout the oceanic area, calcium contents at definite depths were interpolated on the charts of vertical distributions of calcium in the five stations 64, 65, 67, 69 and 71 (Table IV). These interpolated estimates were plotted in Figure 4, illustrating a probable aspect of the vertical distribution of calcium in the present area.

TABLE IV - Probable distribution of calcium in the Southern Atlantic water off South Brazil, as interpolated at definite depths

(I) Calcium content $(\mathrm{mg} / \mathrm{kg})$ :

\begin{tabular}{|c|c|c|c|c|c|c|}
\hline \multirow{2}{*}{ Depth (m) } & \multicolumn{5}{|c|}{ OBSERVED STATIONS } & \multirow{2}{*}{ Average } \\
\hline & St. 64 & St. 65 & St. 67 & St. 69 & St. 71 & \\
\hline 0 & 552 & 436 & 430 & 441 & 439 & $440 \pm 2.4$ \\
\hline 10 & 426 & 420 & 420 & 447 & 442 & $431 \pm 2.8$ \\
\hline 25 & 436 & 430 & 436 & 444 & 428 & $435 \pm 1.9$ \\
\hline 50 & 438 & 435 & 437 & 433 & 434 & $436 \pm 0.7$ \\
\hline 75 & 438 & 439 & 431 & 441 & 424 & $435 \pm 2.1$ \\
\hline 100 & 435 & 439 & 435 & 435 & 429 & $435 \pm 1.2$ \\
\hline 150 & 435 & 442 & 431 & 434 & 422 & $433 \pm 2.2$ \\
\hline 200 & . 446 & 441 & 425 & 441 & 421 & $435 \pm 1.0$ \\
\hline 300 & 437 & 441 & 421 & 436 & 424 & $432 \pm 2.6$ \\
\hline 400 & 423 & 441 & 423 & 428 & 428 & $428 \pm 2.2$ \\
\hline 500 & 416 & 437 & 417 & 417 & 428 & $423 \pm 2.4$ \\
\hline 600 & 430 & 429 & 410 & 413 & 422 & $421 \pm 2.7$ \\
\hline 700 & - & - & 407 & - & 413 & (410) \\
\hline
\end{tabular}

(II) $\mathrm{Ca} / \mathrm{Cl}\left(\times 10^{-3}\right)$ :

\begin{tabular}{|c|c|c|c|c|c|c|}
\hline \multirow{2}{*}{ Depth (m) } & \multicolumn{5}{|c|}{ OBSERVED STATIONS } & \multirow{2}{*}{ Average } \\
\hline & St. 64 & St. 65 & St. 67 & St. 69 & St. 71 & \\
\hline 0 & 22.24 & 21.27 & 21.05 & 21.70 & 21.55 & $21.56 \pm 0.14$ \\
\hline 10 & 21.00 & 20.60 & 20.57 & 22.05 & 21.67 & $21.18 \pm 0.20$ \\
\hline 25 & 21.38 & 21.05 & 21.40 & 21.90 & 21.35 & $21.42 \pm 0.09$ \\
\hline 50 & 21.45 & 21.20 & 21.40 & 21.28 & 21.46 & $21.36 \pm 0.03$ \\
\hline 75 & 21.55 & 21.55 & 21.18 & 21.70 & 20.90 & $21.38 \pm 0.10$ \\
\hline 100 & 21.46 & 21.46 & 21.42 & 21.50 & 21.55 & $21.48 \pm 0.07$ \\
\hline 150 & 21.52 & 21.46 & 21.40 & 21.55 & 21.46 & $21.48 \pm 0.02$ \\
\hline 200 & 22.28 & 21.90 & 21.27 & 22.09 & 21.50 & $21.72 \pm 0.14$ \\
\hline 300 & 22.22 & 22.40 & 21.42 & 22.25 & 21.75 & $22.01 \pm 0.12$ \\
\hline 400 & 21.88 & 22.55 & 21.68 & 21.95 & 22.24 & $22.06 \pm 0.10$ \\
\hline 500 & 21.75 & 22.50 & 21.45 & 21.62 & 22.25 & $21.91 \pm 0.35$ \\
\hline 600 & 22.30 & 22.45 & 21.22 & 21.60 & 22.05 & $21.92 \pm 0.15$ \\
\hline 700 & - & - & 21.42 & - & 21.75 & $(21.58)$ \\
\hline
\end{tabular}

As illustrated in Figure 4 the curve of calcium distribution comprises two characteristic portions, the upper part from the surface to a depth of $200 \mathrm{~m}$ which shows a lower ratio of $\mathrm{Ca} / \mathrm{Cl}$ than the other, the lower part." This feature of the calcium distribution demonstrates a reasonable analogy to its corresponding oceanographic conditions. That is to say, the water of the Brazil Current, or the surface layer of the Central Water, has a lower value (near to $\left.21.4 \times 10^{-3}\right)$ in $\mathrm{Ca} / \mathrm{Cl}$ than does the portion of the protopheric water underneath, with a value of $22.1 \times 10^{-3}$ in $\mathrm{Ca} / \mathrm{Cl}$. An interesting discontinuitylayer is found at the depth of $200 \mathrm{~m}$ when geochemical and hydrodynamical characters of this area of the South Atlantic are taken into consideration. This geochemical analogy demonstrates how it is possible to use the $\mathrm{Ca} / \mathrm{Cl}$ factor of the water as an appreciable index for distinguishing between different water masses in a certain area. The comparative abundance of calcium in the subsurface layer (at 200-650 m depth) of the Central Water may be affected by an effective admixture at the region of the Subtropical Convergence between the less calcareous water of the Brazil Current and the Southern Cold Water rich in calcium content. Thus, such a geochemical study may give a significant proof of DEFANT's definition concerning the hydrodynamical motion of the upper water of the Southern Atlantic 


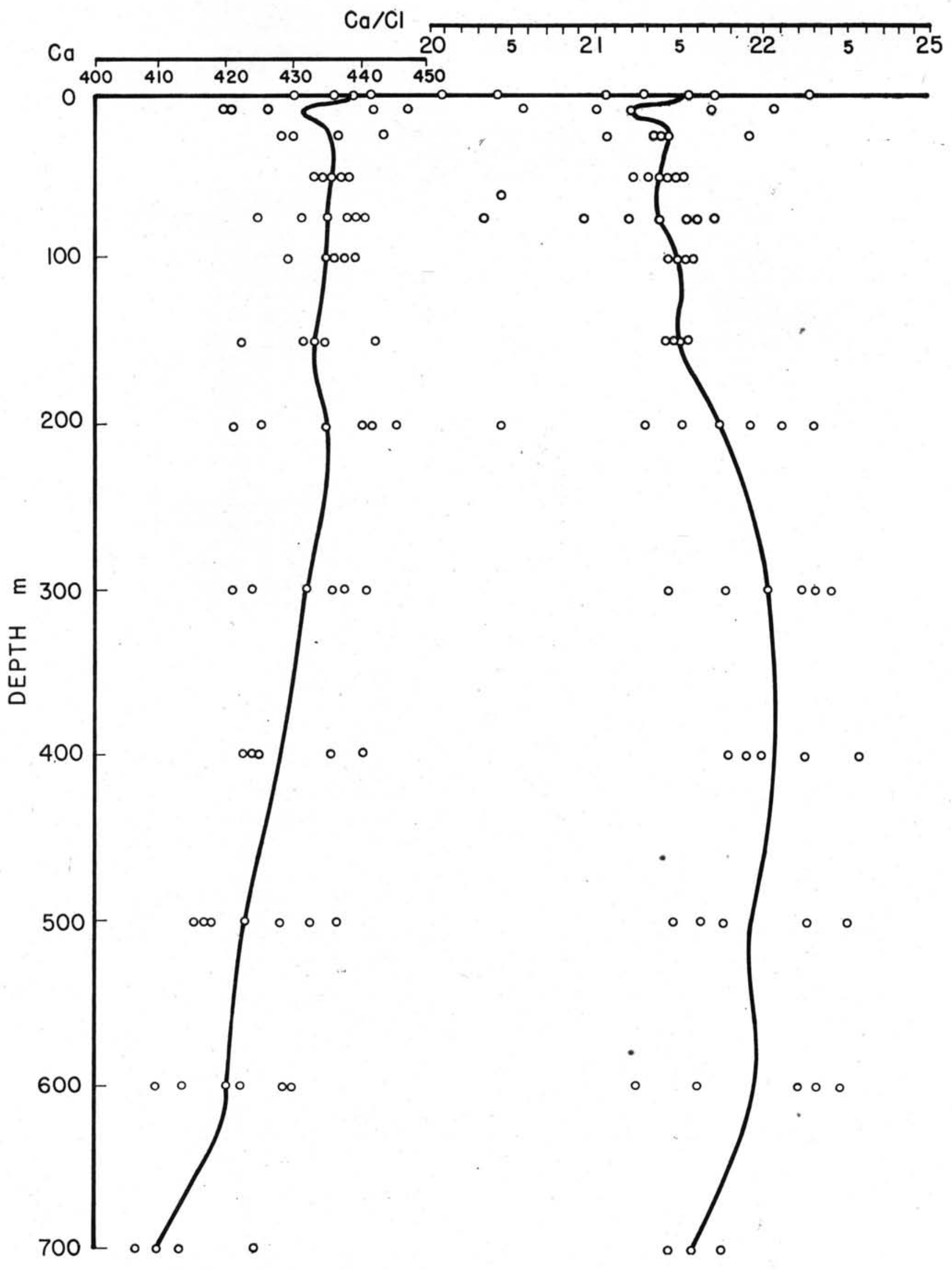

Fig. 4 - Probable distribution of calcium in the Atlantic water off Brazil. 
Ocean. Further, the remarkable depression of $\mathrm{Ca} / \mathrm{Cl}$, observed in the water of the Brazil Current can be connected to a great extent with the following hydrographical conditions.

The Benguela Current, which is the most outstanding current in the Southern Atlantic, proceeds northwards along the western coast of Africa. Under the influence of the prevailing southerly and southwesterly winds the surface layers are carried away from the coast, and upwelling of water from moderate depths takes place during most seasons of the year. As a consequence of this upwelling a fair amount of calcium is brought to the upper layer from a moderate depth. Proceeding towards the Equator, the Benguela Current gradually moves away from the coast and continues as the northern portion of the South Equatorial Current, from which a southern flowing current branches off and moves along the South American coast. It forms a tongue of water of high temperature and high salinity, the Brazil Current.

As pointed out by Revelle (1934), the increase in salinity and temperature and the decrease of the partial pressure of carbon dioxide, observed in the surface water, seems to favor the precipitation of calcium carbonate. The salinity effect (W BERG, 1939) is relatively small, and thus, areas of high or rising temperature will be those where precipitation of calcium carbonate is most likely to occur. The active photosynthesis by phytoplankton will also promote the precipitation because of its great consumption of carbon dioxide. Thus, the water which left the western coast of Africa moves under strong solar radiation in the equatorial region. Accordingly a high elevation of the water temperature causes quite a decrease in the solubility of calcium carbonate and induces an appreciable precipitation of calcite. Microcrystalls of calcite will be suspended in colloidal state in the water and will tend to accumulate at a boundary zone where the region of contact between two different water masses occurs. Over this discontinuous, layer, the deviation of the hydrodynamical density between the contacting waters tends to alter the sedimentation velocity of the suspended particles such as the calcite microcrystalls. As illustrated in Figure 2, several maxima peaks of the $\mathrm{Ca} / \mathrm{Cl}$ factor demonstrate the characteristic accumulation of suspended calcite particles, as mentioned above, at the discontinuity layers. A similar aspect of the physical accumulation of colloidal materials, over a discontinuity layer, such as a thermoclyne, for example, has also been observed in the Bering water, in the Northern Pacific, by the chemical determination of particulate iron and the optical measurement of the intensity of the photoscattering in the water (KATO, 1956).

A relatively low haline water of approximately $34.5 \%$, as observed over a narrow shelf of the Brazilian coast, may suffer the influence of some kind of upwelling from a moderate depth considering the analogy of the salinities in both layers the surface and the deeper one (Emilsson, private information). The upwelling is difficult to prove merely by means of a dynamical examination, but an examination of the calcium content of the water may contribute to solve this problem. Namely, in both waters of the shelf and of moderate depth an analogous high value of the $\mathrm{Ca} / \mathrm{Cl}$ factor was observed. This analogy suggests an intimate relation between these layers from the oceanographical point of view. It is also true, in general that a terrigenous supply of calcareous land-water to the coastal sea water tends to increase the calcium quantity in the latter. However, in the southern Brazilian coast, admixture of land water to the coastal sea water can not contribute to the increase in calcium quantity in the latter because the land water in Brazil is very poor in calcium (KLEEREKOPER 1944; Kato 1966a, b). Consequently a high estimate of $\mathrm{Ca} / \mathrm{Cl}$ observed in the shelf water supports the explanation that a characteristic upwelling occurs from a subsurface layer off the southern Brazilian coast.

The amount of calcium in the sea water has also a close relation to the actual distribution of organisms and the chemical composition of their skeletons (Vinogradov, 1953). The tropical part of the ocean, with a high temperature and a low partial pressure of carbon dioxide, is saturated or supersaturated with calcium carbonate, especially in the upper layers. As a rule, there is a relation between the distribution of organisms and the calcium carbonate, not only for a remarkable concentration of organisms as the coral formations, but for all invertebrates with calcareous skeletons. Consequently, a slight divergence in the actual concentration of calcium in sea water has influence on the development of marine organisms. The direct use of calcium by calcareous invertebrates and the pronounced lowering of the partial pressure of $\mathrm{CO}_{2}$ due to active photosynthesis of the phytoplankton tends to diminish the quantity of calcium in the water of the euphotic zone.

A distinct minimum of calcium content is observed (Fig. 3) in the subsurface layer at the depth of about $50 \mathrm{~m}$, in which the saturation percentage of dissolved oxygen in the water indicates an extremely low value near to $70 \%$. This coincidence between the values may demonstrate that an active development of organisms in the zone induces a remarkable demand of calcium as well as a respiratory consumption of dissolved oxygen. The distribution of calcium as mentioned above is noteworthy as it demonstrates a close correlationship between living beings and their biochemical environment.

\section{RES UMO}

Foi estudada, quìmicamente, sob o ponto-de-vista oceanográfico, a distribuição regional do cálcio em águas atlânticas do sul do Brasil, por meio de análises do conteúdo de cálcio de 78 amostras de água coletadas ao largo da costa do Estado de São Paulo. Empregou-se, nessas análises, a titulação complexométrica com reagente EDTA, obtendo-se resultados satisfatórios.

O conteúdo de cálcio nas águas da área em questão está em relação quase direta com a clorinidade, sendo de $21,56 \times 10^{-3}$ o cálculo de $\mathrm{Ca} / \mathrm{Cl}$. Foi concedida uma margem para o estrôncio incluído no cálculo do cálcio. $\mathrm{O}$ cálculo de $\mathrm{Ca} / \mathrm{Cl}$ mencionado 
acima é quase o mesmo do apresentado por outros pesquisadores e o fator $\mathrm{Ca} / \mathrm{Cl}$ das águas do Atlântico parece mais baixo do que o das águas do $\mathrm{Pa}$ cífico.

É interessante notar que a distribuição do cálcio na água demonstrou uma estreita correlação com as condições oceanográficas da área em questão. Isto significa que a água de superfície da corrente do Brasil apresenta um valor de $\mathrm{Ca} / \mathrm{Cl}$ relativamente baixo, 21,4 $\times 10^{-3}$, comparando-se com o das águas intermediárias, $22,0 \times 10^{-3}$ ou mais. Uma correlacão tão estreita entre êles indica que, certamente, o fator $\mathrm{Ca} / \mathrm{Cl}$ pode ser uma solução apreciável para distinguir as diferentes massas de água de uma determinada área.

Na estação oceânica (St. 69) observou-se uma zona caracterìsticamente "de mínima" em conteúdo de cálcio, na camada logo abaixo da superfície, aproximadamente a $50 \mathrm{~m}$ de profundidade. Essa zona "de mínima" poderia ser atribuída a uma propagação intensa de populaçōes de zooplâncton, cuja respiração ativa produziu um consumo considerável de oxigênio dissolvido, ou seja, $70 \%$ em grau de saturação nas águas dessa zona.

Êsse aspecto da distribuição do cálcio constituirá fator digno de nota para se demonstrar a intima correlação existente entre os organismos consumidores de -cálcio e as suas condições bioquímicas e ecológicas.

\section{REFERENCES}

Bruneau, L., Jerlov, N. G. \& Koczy, F. F.

1953. Physical and chemical methods. Rep. Swed. deep Sea Exped., 1947-48, vol. 3, p. 99 .

Chow, T. J. \& Thompson, T. G.

1955. Flame-photometric determination of strontium in sea water. Analyt. Chem., vol. 27, p. 18 .

1955. Flame-photometric determination of calcium in sea water and marine organisms. Analyt. Chem., vol. 27, p. 910.

EMILSSON, I. 1956.

Relatório e resultados físico-químicos de três cruzeiros oceanográficos. Contrções Inst. oceanogr. Univ. S Paulo, sér. Ocean. fís., n. ${ }^{\circ} 1,70 \mathrm{p}$.

GRIPENBERG, $\mathrm{S}$.

1937. The calcium content of Baltic water. J. Cons. perm. int. Explor. Mer, vol. 12, n. 3 , p. 293-304.

KATO, K.

1956. Particulate iron in the Behring Sea. Bull. Fac. Fish. Hokkaido Univ., vol. 7, p. 291.

1966a. Studies on calcium content in sea water. I. Chelatometric determination of calcium in sea water. Bolm Inst. oceanogr., vol. 15, n. $^{\circ} 1$, p. $25-28$. 1966b. Studies on calcium content in sea water. III. Calcium in the waters of Cananéia lagoon and its adjacent regions, State of São Paulo, Brazil. Bolm Inst. oceanogr., vol. 15, n. $^{\circ} 1$, p. $41-45$.

KIRK, P. L. \& MOBERG, E. G.

1933. Microdetermination of calcium in sea water. Ind. Engng. Chem. analyt. Edn, vol. 5 , p. 95 .

KLEEREKOPER, $\mathrm{H}$.

1944. Introdução ao estudo da limnologia. Rio de Janeiro, Min. Agric., Serv. Inf. Agric. 329 p.

Lyman, J. \& Fleming, R. H.

1940. Composition of sea water. J. mar. Res. vol. 3 , p. 134

MrYake, Y.

1939. Chemical studies of the Western Pacific Ocean. Bull. chem. Soc. Japan, vol. 14, p. 29 , p. 55 .

Revelle, R.

1934. Physico-chemical factors affecting the solubility of calcium carbonate in sea water. J. sedim. Petrol., vol. 4, p. 103

SchWARzenbach, G.

1957. Complexometric tritations, translated by I. Irving. London, Methuen \& Co., $132 \mathrm{p}$.

SugaWARA, K.

1955. Determination of some minor bioelements in Western Pacific water. Comm. Regional Symposium of Physical Oceanography, Tokyo.

Sverdrup, H. U., Johnson, M. W. \& Fleming, R. H.

1942. The oceans: their physics, chemistry and biology. New York, Prentice-Hall, 1087 p.

Thompson, T. G. \& Wright, C. C.

1930. Ionic ratios of the waters of the North Pacific Ocean. J. Amer. chem. Soc. vol. 52 , p. 915 .

Vinogradov, A. P.

1953. The elementary chemical composition of marine organisms. Mem. Sears Found. Mar. Res., n. ${ }^{\circ} 2$, p. 647

WATTENBERG, $\mathrm{H}$.

1933. Kalziumkarbonat- und Kohlensäuregehalt des Meerwassers. Wiss. Ergebn. dt. atlant. Exped. 'Meteor', vol. 8, 333 p.

1936. Kohlensäure and Kalziumkarbonat in Meere. Fortschr. Miner. Kristalogr. Petrogr., vol. 20, p. 168 (Cf. SverdRuP et al., 1942). 